\title{
Spiritual Moral Leadership of Head ECE in Improving Character Learning Through Outing Program
}

\author{
Imron Arifin \\ State University of Malang, Malang, Indonesia \\ e-mail: $\underline{\text { imron.arifin.fip@um.ac.id }}$
}

\begin{abstract}
Early childhood education is a fundamental educational process. This study aims to find out how the spiritual leadership of the spiritual head ECE in improving character learning through outing program. This research uses a qualitative approach, with case study design. Techniques of collecting data using interviews, observation, and documentation. Data analysis is done at the time of data collection and after all, data collected. The data validity test is done with credibility, dependability, and confirmability. The results of the study found that the spiritual leadership of the ECE head is divided into educational, moral, and spiritual leadership. Outing activities in early childhood education institutions consist of outbound activities, moving home, family inn, excursion, visitation figures, and social benefits. Strengthening character education is effective because the spiritual moral leadership of ECE heads has a positive influence and influence on learning achievement and play of early childhood learners.
\end{abstract}

Keywords: $\quad$ spiritual moral leadership, early childhood, character, outing program

\section{INTRODUCTION}

The various societal changes and multidimensional crises that have plagued Indonesia since the reform era of 1998, this has led to two major challenges. First, the emergence of new moral decadence and morality as a hedonistic materialist lifestyle. Second, the emergence of countertransnational radicalism against the life of the nation and the state is accompanied by the movement of terrorism. Mulyasa also sees a multidimensional crisis impacting on the leadership side [1]. This decade, rarely found figure ideal leader who has a high commitment to the task and responsibility. In many areas of life, many leaders are actually less worthy to carry out the mandate of leadership. According to Imron Arifin post-reform era, the multi-dimensional crisis has devastated the structure of life of the Indonesian nation, including national education, after the field of food and health [2]. Faced with this challenge, the government in the field of education is very aggressively promoting and socializing the strengthening of character education from early childhood education to higher education.

In every educational unit entity, including early childhood education is always led by the principal. The principal has two dual roles as the educational leader and as the school manager [3]. As a leader, the principal is required to influence others, subordinates or groups to have special skills or expertise in the field desired by the group and achieve the goals of the school organization. One of the principal's leadership missions inspires, creates, and innovates activities or actions that can succeed character education.

Some researchers found that moral leadership-based moral leadership is effective in the implementation of character education [4], [5]. Leaders are not only people with vast spiritual knowledge but also more emphasis on spiritual consciousness, it is a broad understanding and totality of life. Spiritual leadership is a model of ethical, spiritualist, and spiritual leadership [6]. If Levin (2008) states that spiritual intelligence is the highest level of intelligence, spiritual leadership is leadership that uses all levels of high intelligence. So it is true if spiritual leadership is a comprehensive leadership model that unifies various approaches and leadership powers to move passions such as intellectual, moral, emotional and spiritual forces.

Schools as a leader in quality improvement and leading and highly strategic change agents, especially the principal's leadership role in improving the quality and strengthening of character education. Character education is given from early childhood education. Learning and play activities in early childhood education are conducted through indoor, outdoor, and outing programs. It is interesting and important to examine the role of moral-spiritual leadership in character building through outing programs in early childhood education. This study aims to describe the role of spiritual moral leadership of ECE Head in 
Improving Character Learning through outing program.

\section{RESEARCH METHODS}

This study used a qualitative approach, a multi-site study design with a modified induced induction approach, while theoretical orientation using phenomenology. Research location in three ECE in Malang City. Data collection was done by participant observation, in-depth interview and documentation. Data analysis was performed at the time of data collection and after all data collected, through two stages, first with the analysis of individual sites with flow models, and both crosssite data analysis. Data analysis techniques using interactive patterns of data in data collection, data reduction, display data and conclusion drawing and verifying. Data validity is done by credibility, transferability, dependability, and confirmability.

\section{RESEARCH FINDING and DISCUSSION}

\subsection{Head of ECE as Education Leader}

ECE head educational leadership requires creativity, innovation, resourcefulness in addition to demanding more vigorous work, hard, and expertise to move and inspire teachers to carry out character learning. The role of educational leadership is found through leadership roles of supervision, leadership, and team leadership. In the supervision leadership, the ECE head conducts professional teacher training in initiating character learning activities through indoor, outdoor, and outing programs. The leadership of learning is demonstrated by incorporating the idea of character learning through themes that are integrated into established programs [8]. Team leadership is demonstrated through the strength of team works between principals, teachers, and parents in implementing established programs. ECE heads form a solid working team, motivate, identify needs and reduce the emergence of potential conflict early on. The findings of this research are in line with Sergiovanni theory which presents six principal leadership roles, namely: formal leadership, administrative leadership, supervision leadership, organizational leadership, and team leadership [9].

Formal leadership refers to the task of the Head of ECE to formulate the vision, mission, and objectives of the organization in accordance with the basic and applicable regulations. Administrative leadership refers to the principal's duty to foster the administration of all staff and members of the school organization. Supervisory leadership refers to the principal's duties to assist and guide members in order to perform the task well. Organizational leadership refers to the principal's job to create a conducive working climate so that members can work energetically and productively. Team leadership refers to the task of ECE Head to build good cooperation among all members in order to realize the goal of school organization optimally.

\subsection{Leadership of Moral-Based Early}

\section{Childhood Education}

The leadership of ECE head shows moral values by doing effective communication skills, based on Islamic moral values. In the supervision and parenting education activities, the ECE head always informs and communicates the moral values taught by religion. Elderly moral based heads are always oriented towards leadership that prioritizes and holds strong aspects of humanity, politeness, and decency. The findings of this study are similar to moral leadership research conducted by Jentile (2016) that moral is important to see whether leaders have good ethics. When a leader's behavior is done in a respectful, noble, and fair way, it will have a direct impact on follower motivation. Character, morality, and ethics need to be addressed with effective leadership [11], [12]. Moral leadership focuses on moral and ethical values that encourage the birth of good behaviors. Moral leadership concerns the civilized man's character. Moral also means good and bad doctrine, deeds, and behavior (morals). Moralization, meaning descriptions (views, teachings) of actions and good behavior. On the contrary, acts that indicate moral damage are called demoralization [13], [14]. The moral in the perspective of Islamic teachings is known as morals. Morals in terms of language come from the word "khulq" which means behavior, temperament or character [15].

Sources of morals or morals originate in the guidance of God, as mentioned in the hadits. Narrated from Sa'd ibn Hisham, he said: I asked 'A'ishah: "O Ummul Mukminin, tell me about the morality of the Prophet Sallallahu' Alayhi wa Sallam". 'A'ishah replied: "His morality is the Qur'an." (HR Ahmad)

Early Childhood Education (ECE) as a preschool education that foster children aged 0-6 years which is the golden age of a child in his growth 
absolutely has a leader who has a high moral. The moral is then manifest in the attitude and behavior of the principal. A virtuous schoolmaster or noble character will be able to display humble, ethical and high-integrity behavior that becomes a profile for schoolchildren to emulate and emulate. Moral elevation for a principal especially in the early childhood environment is a necessity and educational demands as set out in Permendiknas No. 13 of 2007 on Principal / Madrasah Certification [16].

On the charge of Permendiknas mentioned that the principal (including ECE head) must have five basic competencies, namely: personality, managerial, entrepreneurial, supervision, and social competence. In the competence of personality (personality competence) mentioned indicator achievement include: (1) noble character, by developing culture and traditions noble character and become exemplary noble character for the community in school/madrasah; (2) has the integrity of personality as a leader; (3) have a strong desire in self-development as principal/madrasah; (4) being open in carrying out basic tasks and functions; (5) self-control in facing problems in work as principal / madrasah; And (6) have the talent and interest of office as education leader [17].

\subsection{Leadership of ECE-Based}

\section{Spiritual Head}

Spiritual leadership is the same as leadership in general but rather leads leadership based on religious teachings. This study found the leadership of ECE head that always shows three aspects, which invites all elements of school to always believe, piety, and morals karimah. In the implementation of the program outing ECE head incorporates elements of faith, taqwa, and morals as an important and major part, both on outing activities for children and parenting activities in the outing. This finding is consistent with Juharyanto's study (2017) that defines spiritual leadership as a leadership that brings worldly dimensions to the divine dimension. Therefore, spiritual leadership is based on religious ethics and spiritual intelligence and is based on faith and conscience.

Spiritual leadership is a comprehensive leadership model that combines multiple approaches as well as the driving force of leadership. This leadership is a combination of ethical, ascetic, and mystical leadership [18], [19]. Spiritual leadership is more based on faith and conscience in the quality of leadership by cleansing the heart, giving, serving, enlightening and winning souls based on the spirit of gratitude and love [19]. Conscientious leadership is a leadership that views organizational members as complete human beings encompassing four dimensions: body/physical, mind, heart, and soul. This view supports the complete fulfillment of human foundation to provide total motivation: to live, to love, to learn, and to leave a legacy [19].

There are two models in spiritual leadership, namely (1) substantive spiritual leadership and (2) instrumental spiritual leadership [20]. Substantive spiritual leadership is the spiritual leadership born of the spiritual devotion of the leader and the proximity of the leader to the divine realities and the world of the spirit. His spiritual leadership model came into being by itself and blended into his daily personality and behavior and was therefore fixed. Next, the instrumental spiritual leadership, the spiritual leadership learned and then the leadership style of the leader. The spiritual leadership style of a leader arises because of external demands and becomes a tool or medium to streamline his leadership behaviors.

The results of Percy's study show that successful directors and Chief Executive Officers (CEOs) in life and leadership have a high spirituality and impose a spiritual leadership style (http://lppks.org) [21]. Spiritual leadership is leadership in the name of God. Therefore, the ethical reference as the basis of his leadership behavior stems from the attributes of God, such as $A r$ Rahman (Supreme), Ar-Rahim (Supreme Being), so a leader must spread love and affection to his followers, and the attributes of God Others. Thirdly, axiologically, the leadership is for welfare through power, empowering the led people, enlightening the mind, cleansing the heart, the conscience of the conscience, and the liberation of the soul towards a better life [22], [23].

Through spiritual leadership strived to achieve happiness of life, health, honesty, welfare, love, empowerment, intrinsic truth and positive attitude [19], [22]. Forum Group Discussion conducted by Harvard Bussiness School, which was attended by CEOs of leading companies in the United States including those from "Silicon Valley" resulted in an agreement that spiritualism is capable of producing 5 things; (1) integrity or honesty, (2) energy or spirit, (3) inspiration or idea and initiative, (4) wisdom or wisdom, and (5) courage in making decisions. All agree and agree that spirituality proves to lead one to the ladder of success and play a role in creating them into a powerful leader [24]. 


\subsection{Spiritual Moral Leadership in}

\section{Character Learning Outing Program}

Outing programs at early childhood
education institutions are conducted through
outbound activities, moving home, family inn,
excursions, visit prominent figures and social care.
The leadership of ECE-based moral-spiritual head in
implementing these programs always put forward
moral values (akhlak al-karimah). In moving house
and family in activities, it always emphasizes the
ethics of communicating, communicating, and
socializing according to moral-spiritual values, as
well as outbound activities, excursions, character
visits, and giving compensation to prejudice and
orphans.

The leadership of ECE heads synergies the morality of the worldly dimension to the spiritual or divine dimension. God as the inspiration for the true leader, enlightens, cleanses the conscience and soothes the souls of his servants in a very wise way through ethical and exemplary approaches [3]. There is an equivalence between a moral-spiritual headmaster's leadership and a character-based principal so that spiritual moral leadership can be explained by a character-based leadership approach. In relation to the characteristics and competencies of the principal has been described in Permendiknas No. 13/2007 that the principal must meet the requirements especially on the fulfillment of personal competence and social competence as the main capital in communicating and interacting effectively with the school environment and outside school [25], the principal seeks to develop communication with Parents, students, residents of the school, so as to establish sustainable two-way communication [26], sustainable, healthy, positive, communicative and constructive [27].

The social competence of the principal is marked: (1) skillfully cooperating with others who are mutually beneficial and beneficial; (2) able to participate in social activities; and (3) have a social sensitivity to other people or groups (Permendiknas No. 13/2007). Arifin (2016) adds that in addition to the five competencies established by the Indonesian government, other relevant competencies such as spiritual competence are characterized by the transcendental spiritual dimension of faith, devotion and other religious commitment values [29], [30], this competency is needed in religious schools, madrasah, and education in boarding school environment. In other words, the principal is not just a personality and social competence, but the competencies are based on devotion, so that it becomes personal piety and social piety, perhaps cultural piety, economic piety, and national piety. Piety referred to as a spiritual foundation, which is in accordance with the meaning of the precepts of the Supreme Godhead in Pancasila.

The essence of the principal's leadership in developing early childhood character education is leadership that develops the primary school potential of learners as good learners (good knower) who are always bound in thinking (fikr), feeling (dhikr) and acting $\left(f i^{\prime} i l\right)$ To the values of goodness. More than that for the Islamic education environment would be a spiritual base of goodness that is usually known in the environment of boarding schools, madrasah, diniyah, and Islamic schools with material aqidahakhlak. How these aqidah-akhlak not only stop at knowing, but also a feeling and action. The most effective strategy is to teach "exemplary and moralbased inspiration or character and initiated by the principal as an inspiring leader" [27].

The success of character education for early childhood is dependent on the presence or absence of awareness, understanding, awareness, and commitment of various parties to education. Kilpatrick that one of the causes of someone behaving well despite having an understanding of moral understanding due to not training to moral conduct [1]. Therefore, character education for early childhood should be realized through concrete action in learning, not too theoretical, and not limited to learning activities that are limited in indoor classrooms.

The findings of this study are illustrated in Figure 1.

\section{CONCLUSIONS}

The conclusions can be obtained from the results of this study. First, the characteristics of moral-spiritual leadership ECE head is divided into 3 characteristics of leadership, the namely leadership of education, moral leadership, and spiritual leadership. Educational leadership consisting of leadership supervision characteristics, leadership, and team leadership. Moral leadership conducted by ECE head is based on moral values derived from community norms and religious teachings, moral behavior as role models, and spirit and commitment of moral learning. ECE spiritual leadership is characterized by the learning of faith, devotion, and the great morality (akhlak al-karimah) based on the teachings of religion (Islam). 
Second, outing activities in early childhood education institutions consist of outbound activities, moving home, family inn, excursion, visit prominent figures, and social care. The spiritual moral leadership of the ECE head is internalized in the character-learning program through the program of activity. Strengthening character education is effective because the spiritual moral leadership of ECE heads has a positive influence and influence on learning achievement and play of early childhood learners.

\section{REFERENCES}

[1] E. Mulyasa, Manajemen ECE. Bandung: PT Remaja Rosdakarya, 2012.

[2] Imron Arifin, Kepemimpinan Kepala PAUD dalam Mengimplementasikan Pembelajaran Sentra: Studi Kasus PAUD Unggulan Nasional Anak Saleh Malang. Yogyakarta: Aditya Media, 2012. ISBN 978-979-398419-3

[3] Imron Arifin, Kepemimpinan Kepala Sekolah dalam Mengelola Sekolah Berprestasi: Studi Multi Kasus pada MIN Malang I, MI Mamba'ul Ulum, dan SDN Ngaglik I Batu Malang. Yogyakarta: Aditya Media, 2010. ISBN 978-979-3984-42-1

[4] M. Kimber and M. Campbell, "Exploring ethical dilemmas for principals arising from role conflict with school counsellors," Educ. Manag. Adm. Leadersh., vol. 42, no. 2, pp. 207-225, 2013.

[5] K. Fuller, "Leading with Emancipatory Intent: Headteachers' Approaches to Pupil Diversity," Educ. Manag. Adm. Leadersh., vol. 40, no. 6, pp. 672-689, 2012.

[6] D. J. Parks, J. R. Craig, T. B. Creighton, and A. T. Abel, "An Operational Definition of Spiritual Leadership Kevin G . Bezy Dissertation submitted to the faculty of the Virginia Polytechnic Institute and State University in partial fulfillment of the requirements for the degree of Doctor of Philosophy in Educatio," 2011.

[7] M. C. for U. Education, "Culturally Responsive Classroom Management Strategies," Metrop. Cent. Urban Educ., no. October, pp. 1-10, 2008.

[8] G. C. Ubben, L. W. Hughes, and C. J. Norris, The Principal: Creative Leadership for Effective Schools. Fourth Edition. Boston: Allyn and Bacon, Inc., 2001.

[9] T. J. Sergiovanni and R. L. Green,
Principalship: $A$ reflective practice perspective, 6th ed. Boston: Allyn and Bacon, Inc., 2015.

[10] T. Jentile, "The moral formation , pastoral leadership and contemporary Pentecostal / Charismatic Churches in Soweto," 2016.

[11] Steven G. Koven, Public Sector, no. July. U.S.: Taylor \& Francis Group, 2015.

[12] G. Elliott, "Critical practice leadership in post-compulsory education," Educ. Manag. Adm. Leadersh., vol. 43, no. 2, pp. 308-322, 2013.

[13] K. S. Louis and J. Murphy, "Trust, caring and organizational learning: the leader's role," J. Educ. Adm., vol. 55, no. 1, pp. 103126, 2017.

[14] M. McCarthy, "Reflections on the evolution of educational leadership preparation programs in the United States and challenges ahead," J. Educ. Adm., vol. 53, no. 3, pp. 416-438, 2015.

[15] N. S. Murphy, "Nurse leaders as stewards: the beginning of change," Open Nurs J, vol. 3, pp. 39-44, 2009.

[16] Kementerian Pendidikan Nasional, Peraturan Menteri Pendidikan Nasional RI Nomor 13 Tahun 2007 Tanggal 17 April 2007 Tentang Standar Kompetensi Kepala Sekolah/Madrasah, no. April. Indonesia, 2007, pp. 1-6.

[17] Kemendiknas, Peraturan Menteri Pendidikan Nasional, 2007. Tentang Standar Kepala Sekolah/Madrasah. Jakarta, 2007.

[18] Juharyanto, "Kepemimpinan unggul Kepala Sekolah Dasar Daerah Terpencil (Studi Multisitus pada Sekolah Dasar di Kabupaten Bondowoso)," J. Sekolah. Dasar, vol. 1, no. 1. Tahun 26, 2017.

[19] K. Arar, I. Haj, R. Abramovitz, and I. Oplatka, "Ethical leadership in education and its relation to ethical decision-making: The case of Arab school leaders in Israel," $J$. Educ. Adm., vol. 54, no. 6, pp. 647-660, 2016.

[20] A. Eliyana and D. Ratmawati, "Influence of Transformational Leadership and Organization Climate to the Work Satisfaction, Organizational Commitment and Organizational Citizenship Behavior on the Educational Personnel of," Eur. J. Bus. Manag., vol. 5, no. 10, pp. 97-115, 2013.

[21] I. Percy, Going Deep. Exploring Spirituality in life and leadership. Arizona: Inspired 
Production Press, 2003.

[22] R. Blackaby, "( Moving People On To God ' s Agenda )," 2009.

[23] K. Arar, "Book Review: Women and Educational Leadershipby GroganMargaretShakeshaftCarolSan

Francisco, CA: Jossey Bass, 2011, US\$25.00, ISBN 9780470470435, 131 pp.," Educ. Manag. Adm. Leadersh., vol. 40, no. 5, pp. 641-643, 2012.

[24] Ary Ginanjar Agustian, "ESQ Leadership Center (Online)," 2017. [Online]. Available: www.sqgroup.co.id,. [Accessed: 28-Mar2017].

[25] B. Alma, Kewirausahaan. Bandung: Alfabeta, 2008.

[26] G. Sugiyanto, P. B. Santosa, A. Wibowo, and M. Y. Santi, "Analysis of hub-andspoke airport networks in Java Island, based on cargo volume and freight ratio," in Procedia Engineering, 2015.

[27] Imron Arifin, "Kompetensi Kepribadian Kepala Sekolah Berbasis Moral Spiritual dalam Mengimplementasi Pendidikan Karakter," 2009.

[28] Imron Arifin, "Kepemimpinan Pembelajaran Kepala Sekolah Dalam Menerapkan Pendidikan Karakter Pada Era Masyarakat Ekonomi Asean," pp. 680-692, 2016.

[29] K. Klenke, "Authentic Leadership: A Self, Leader, and Spiritual Identity Perspective," Int. J. Leadersh. Stud., vol. 3, no. 1, pp. 6897, 2007.

[30] K. J. Wilkinson and A. Reinhardt, "Kevin J. Wilkinson and Alain Reinhardt." 2005. 


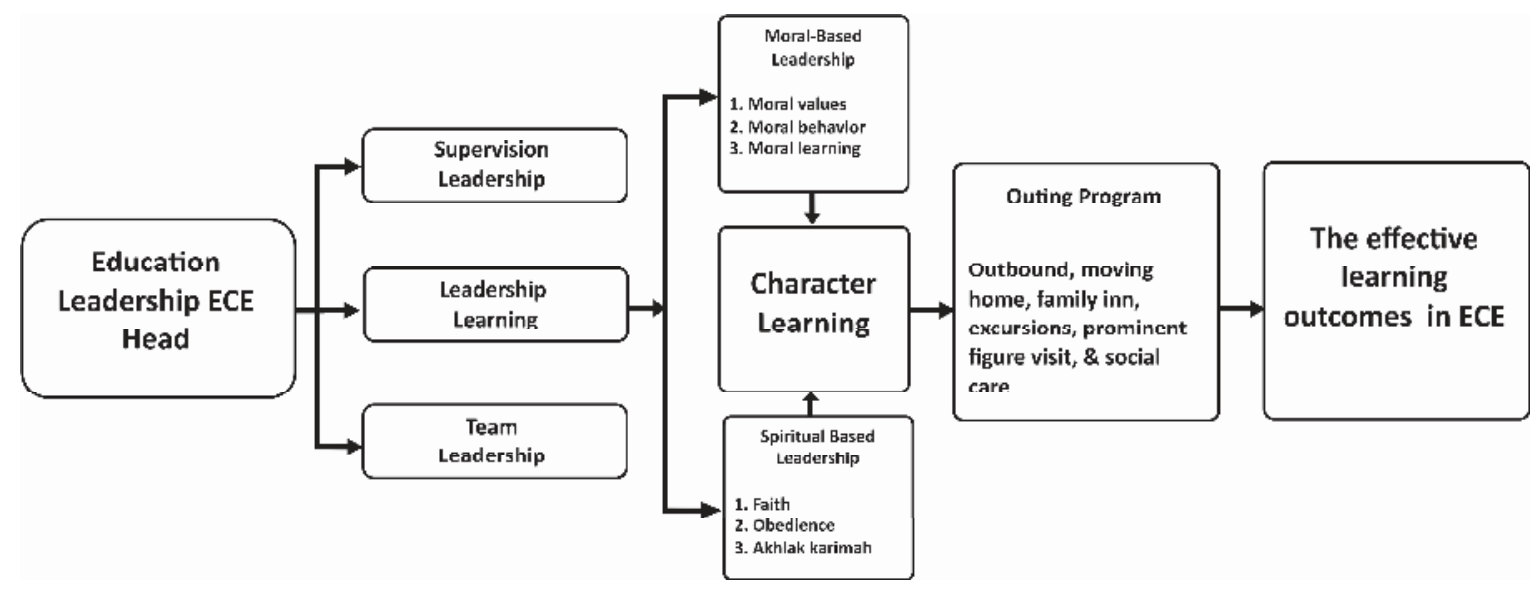

Figure 1. Leadership of PAUL-Based Early Childhood Leadership in Early Childhood Learning through outing program 